\title{
Research and Optimization of Technological Process Based on Fermentation for Production of Seaweed Feed
}

\author{
Ling Han, Shuping Zhang*, Jie Ma, Xiaohui Liu \\ School of Medical Instruments and Food Engineering, University of Shanghai for Science and Technology, Shanghai, China \\ Email: "hlmmc@126.com
}

Received March 5, 2012; revised April 11, 2012; accepted April 15, 2012

\begin{abstract}
This paper for the purpose of utilization, conducted a study of technological process of producing animal feed by fermenting seaweed waste. Anaerobic fermentation, which can improve the contents of protein and polysaccharide in seaweed waste, proved to be an available method to improve the nutritional value of animal feed by using seaweed waste. Also effects of different additives and fermentation time on the fermentation products was compared, combined CCRD with neural network to optimize these factors, the predict model among all factors was established, also obtained the optimal fermentation process.
\end{abstract}

Keywords: Algae Waste; Anaerobic Fermentation; Animal Feed

\section{Introduction}

The seaweed waste, the insoluble fiber residue of which glue, iodine and other substance has been extracted from seaweed waste, mostly used as waste discharged into the natural world directly, that not only caused waste of resources, also resulted in environmental pollution [1], while there are abundant nutrients in the seaweed waste, as high-quality animal feed ingredients, which can effectively improve the immunity of animals and increase the economic benefits $[2,3]$.

Microbial fermentation which is of advantage with short cycle and high efficiency, has been widely used in food, feed and other industries using the characteristics of the microorganism itself contains large amounts of protein, has a promising prospect. Algae residue contains major required nutrients of animal feed: protein, crude fiber and other trace elements, which the protein and crude fiber content is usually $8.86 \%-8.92 \%$ and $43.16 \%-43.65 \%$ respectively [4]. Not only the protein content of algae residue can be increased by using microbial anaerobic fermentation with adding appropriate source of nitrogen and other growth factors, can also make the crude fiber degrade into some monosaccharides and polysaccharides prebiotics which are necessary to animals. This method can effectively improve the nutrient content of the algae residue and enhance its application in animal feed value with the major effects: 1) improve the rumen environment and promote the ecological balance of microorganisms in vivo; 2) improve feed conversion rate; 3 ) produce

"Corresponding author. organic acids [5,6]. Also this method is of low cost of raw materials, simple process and short cycle, and has not been reported before.

Fermentation results mainly influenced by the active of the bacteria agents, while the activity of the bacteria agents are influenced by the environment and dosage of auxiliaries, these factors impact on the fermentation results differently [7], or these are interaction. The experiment using Central Composite Design (CCD) combined with neural network prediction model, is in order to obtain the optimum process conditions.

\section{Materials and Methods}

\subsection{Materials}

Seaweed industrial residues.

\subsection{Major Equipments}

Mill, the production from the Beijing Kun Jie Yu Cheng Machinery Co., Ltd., Model KCS-10; heated oven, the production from Kim Nam Instrument Factory, model DHG-9053A; Biochemical incubator, the production from Hai Qixin Scientific Instruments Co., Ltd., model LRH-70.

\subsection{Main Experimental Methods}

\subsubsection{Fermentation Process}

Seaweed residue was crushed through the mill to a particle diameter of $3 \mathrm{~mm}-5 \mathrm{~mm}$, then added cellulase, potassium dihydrogen phosphate, ammonium chloride, the 
EM inoculants (the EM effective microbial agents is a novel compound microbial preparation, brown translucent liquid, $\mathrm{PH}$ value between 3.5 to 4.5 , the composite culture of photosynthetic bacteria, lactic acid bacteria, yeasts, actinomycetes bacteria, Acetobacter and other five families, 10 are over 80 kinds of anaerobic or suspected of oxygen normal microbiala), Indian meal, lactose and water, later mixed into the airtight container well-proportionally and placed in a biochemical incubator $\left(25^{\circ} \mathrm{C}\right)$ for fermentation, until fermentation is completed and then removed from the container, placed in heated oven $\left(50^{\circ} \mathrm{C}\right)$ to dry.

\subsubsection{Determination of Protein and Polysaccharide Content}

In this study, all the protein and polysaccharide content of samples are determined by Kjeldahl method (GB5511$85)$ (nitrogen protein conversion factor of 5.95) and the phenol sulfuric acid method.

\subsubsection{Experimental Design}

The effect on fermentation products of cellulase, bacteria agents, ammonium chloride and number of days are investigated respectively. Combined with $\mathrm{CCD}$ and General Regression Neural Network (GRNN), protein content and polysaccharide content, two dependent variables, were analyzed to determine the extraction of the optimal process conditions.

\subsection{Data Process Software}

The experimental data was analyzed by the desingexpert6.5, and Matlab2009b software.

\section{Results and Discussion}

\subsection{Effect of Basic Material on Fermentation}

\subsubsection{Effect of Temperature on Fermentation}

Temperature is one of the most important factor to affect microbial growth and reproduction, same microorganisms has the different optimal temperature with variable physiological and biochemical processes, that means, the optimum growth temperature is not equal to the highest incubation temperature, neither does not mean fermentation speed is highest when incubation temperature nor the cumulative amount of metabolites when the incubation temperature, also does not mean the highest amount of incubation temperature either. For instance, Streptococcus thermophilus optimal growth temperature is of $37^{\circ} \mathrm{C}$, the optimal fermentation temperature is of $47^{\circ} \mathrm{C}$, the cumulative product of the optimum temperature is of $37^{\circ} \mathrm{C}$. From Figure 1, the protein content of the fermentation products gradually increased with increasing temperature at the range of $20^{\circ} \mathrm{C}-25^{\circ} \mathrm{C}$, reached the maxi- mum at $25^{\circ} \mathrm{C}$, the protein content decreased with increasing temperature over $25^{\circ} \mathrm{C}$. Apparently microbial enzyme activity will be affected when temperature is higher than $25^{\circ} \mathrm{C}$, which leads to restraint of regular growth and reproduction, resulted in protein and crude fiber content of fermented products has been decreased with increasing temperature. Accordingly, the optimal temperature of the fermentation is of $25^{\circ} \mathrm{C}$.

\subsubsection{Effect of Material-Water Ratio on Fermentation}

Material-water ratios is an important influential factor in solid-state fermentation, extortionate water content will lead to aggregation of medium and cause lower porosity, affect the transfer of oxygen; while water content is too low, medium expansion will be retarded, which is not able to meet the needs of the microbial growth and metabolism, thereby inhibiting cell growth. The experiment has been carried out to study the effect of material-water ration on fermentation; results are shown in Figure 2. According to Figure 2, the material-water ratio had a greater influence on fermented products. Protein and polysaccharide increased gradually while material-water ratio from $50 \%-65 \%$, declined slightly at $70 \%$, and de-

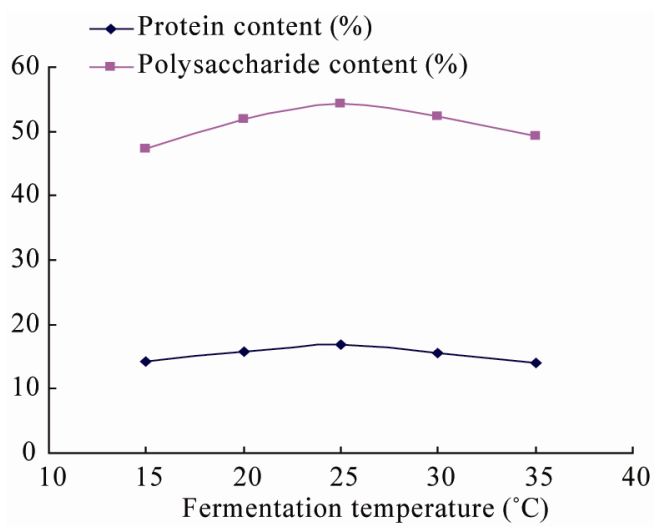

Figure 1. Effect of temperature on fermentation.

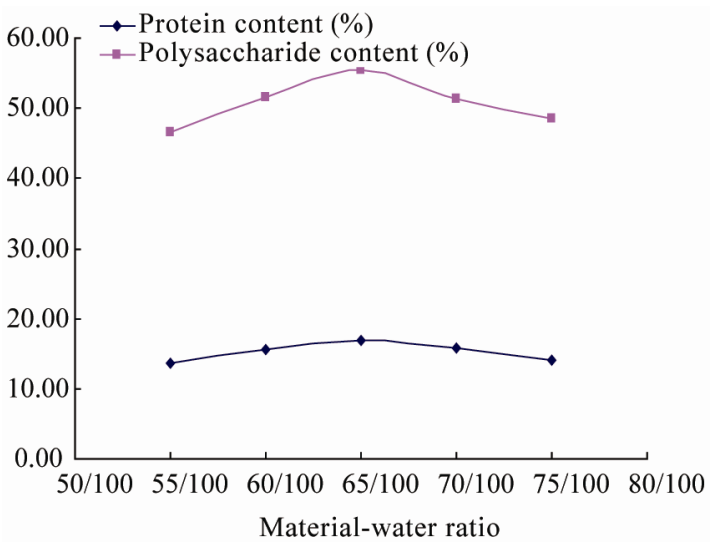

Figure 2. Effect of material-water ratio on fermentation. 
clined sharply from $75 \%-90 \%$. Water-material ratio at the range of $50 \%-65 \%$, seaweed residue is of high hardness, bonded together in lumps, and turn to loose from $70 \%-85 \%$ and semi-liquid at $90 \%$, according to above analysis of data and phenomena, water-material ration at $65 \%$, algae residues is of a fitting loose condition to maintain certain porosity and advantageous to interaction of water and air in solids, so that the dissolved oxygen can be delivered smoothly. Thus, the water-material ratio at $65 \%$, the fermentation products is of the highest protein and polysaccharide content.

\subsection{Single Factor Analysis}

Basic raw materials: seaweed waste $1000 \mathrm{~g}$, water $1500 \mathrm{~g}$, potassium dihydrogen phosphate $10 \mathrm{~g}$, Indian meal $15 \mathrm{~g}$, lactose $15 \mathrm{~g}$.

\subsubsection{Effect of Cellulase on Fermentation}

Under the condition of adding bacteria agents $10 \mathrm{~g}$, ammonium chloride $15 \mathrm{~g}$, fermentation of 10 days to study the effect of cellulase on fermentation. Cellulase can decompose raw materials in the natural cellulose into fermentable sugars, the other hand, cellulase can decompose the cell wall to release protein, starch and other nutrients in it, while the raw fiber can be degraded into the glucose which can be digested and absorbed by livestock. Figure 3 shows that protein and polysaccharide content of fermentation products is $9.58 \%$ and $47.25 \%$ respectively when added $6 \mathrm{~g}$ cellulase, while adding cellulase $10 \mathrm{~g}$, protein and polysaccharide content reaches its maximum $(12.68 \%, 58.45 \%)$, further addition of cellulase protein brought about a downward trend the content of protein and polysaccharide, this is due to the cellulose to cellulase adsorption sites has basically occupied, increasing the amount of enzyme can only increase the adsorption of enzyme invalid, and thus will not significantly im-

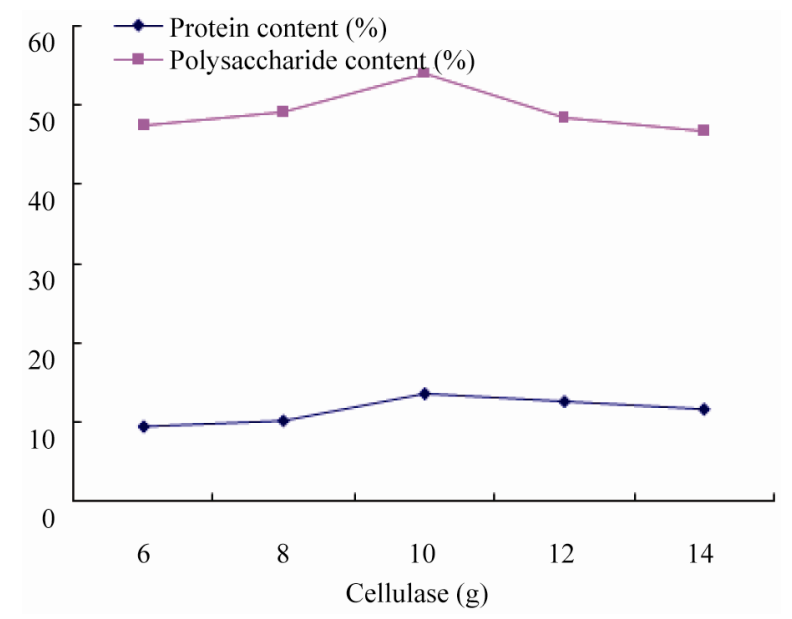

Figure 3. Effect of cellulase on fermentation. prove the effect of fermentation; the other hand, enzyme fermentation environment of excessive make $\mathrm{pH}$ decreased, the agents normal metabolic activity, reduction of the fermentation product. Therefore, $10 \mathrm{~g}$ is an ideal addition amount of cellulase.

\subsubsection{Effect of Bacterial Agents on Fermentation}

Under the condition of adding cellulase $10 \mathrm{~g}$, ammonium chloride $15 \mathrm{~g}$, fermentation of 10 days to study the effect of bacterial agents on fermentation. Figure 4 shows that when less amount of agents was added, the effect of fermentation is poor, protein and polysaccharide content in fermentation products is only $9.23 \%$ and $44.85 \%$, since the synergy and co-residence effect between the microbial, increasing amounts of agents will improve fermentation effect significantly, with the increasing amount of bacteria agents, the maximum protein and polysaccharide content $(12.85 \%, 52.15 \%)$ was got by added agents $8 \mathrm{~g}$, while added bacteria agents amounts further, protein and polysaccharide content presented a downward trend, this may occur because the autolysis of bacteria due to improvement of proteolytic enzyme activity or some bacteria produced antibiotics and other secondary metabolites. Therefore, the amount bacteria agent of about $10 \mathrm{~g}$ is an ideal.

\subsubsection{Effect of Ammonium Chloride on Fermentation} Under the condition of adding cellulase $10 \mathrm{~g}$, bacteria agent $8 \mathrm{~g}$, fermentation of 10 days to study the effect of bacterial agents on fermentation. Adequate source of nitrogen are necessary for microbial propagation to synthesize such as amino acids, nucleic acids and other cellular material and to regulate metabolism, so necessary nitrogen should be added into fermentation, on the other hand, addition of inorganic nitrogen can promote microbial metabolism transformed it into protein, consequently improve the protein content in the algae residue directly.

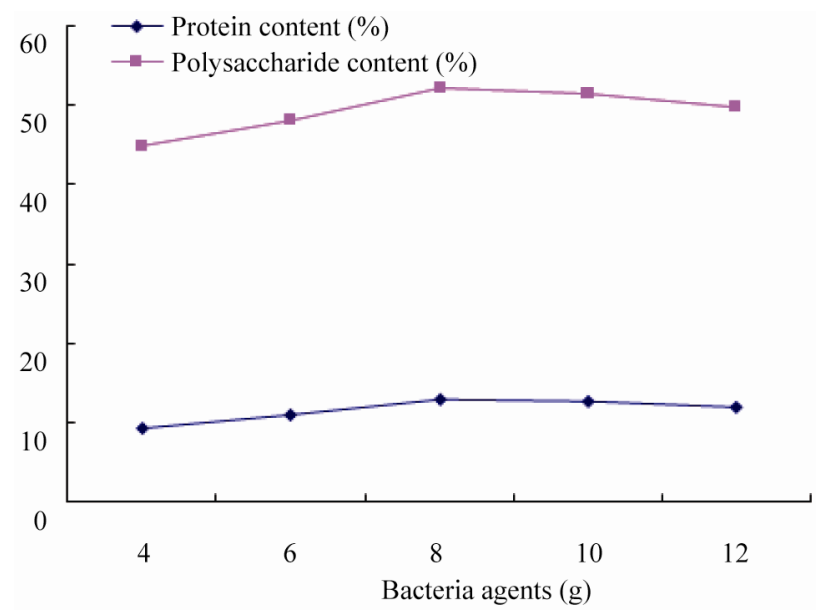

Figure 4. Effect of bacterial agents on fermentation. 
Figure 5 shows that, the best fermentation result was made when ammonium chloride dosage is of $15 \mathrm{~g}$, the content of protein and polysaccharide was $14.85 \%$ and $54.25 \%$ respectively, while increasing ammonium chloride further did not affect the amount of the polysaccharide content, but will caused protein content to decrease significantly, this is because excess ammonium chloride make fermentation environment weakly acidic, thereby affecting the cell structure of bacteria, thus affecting isolates metabolism and product synthesis, so the amount of ammonium chloride, $15 \mathrm{~g}$ best.

\subsubsection{Effect of Number of Days on Fermentation}

Under the condition of adding cellulase $10 \mathrm{~g}$, bacteria agent $8 \mathrm{~g}$, ammonium chloride $15 \mathrm{~g}$ to study the effect of number of days on fermentation. From Figure 6, fermentation time on the fermentation products is a significant, the content of protein and polysaccharide increased while the number of fermentation days increasing, fermentation achieve maximum protein and polysaccharide contents $(14.75 \%$ and $54.13 \%)$ when days of fermentation was 8 , it showed that microbial metabolism entered into stable period gradually in the first 8 days, further increasing of fermentation time over 10 days, the content of crude protein and polysaccharide in fermented product decreased by microbial autolysis, thus, fermentation time of 8 days is optimum.

\subsection{Central Composite Design}

According to the results of univariate analysis, protein and polysaccharide contents of fermentation products were investigated by added different contents of cellulase, bacteria agents, ammonium chloride and different number of fermentation days. Four factors-five level central composite experimental design was established by Design Expert to study the content of protein and polysaccharide. In this study, there are total of 31 experimental points, including 16 factorial points, 7 center points and 8 axial points [8]. The axial point represents the level of the extreme value of each independent variable; Central point represents the center level, repeated seven times to estimate experimental error. Response surface analysis of factors and levels are shown in Table 1, the experimental results are shown in Table 2.

\subsection{Data Processing and Analysis Based on GRNN}

GRNN is a kind of Radial Basis Function (RBF), consists of input layer, radial grass-roots layer and the linear layer. GRNN topology was shown in Figure 7. Because of its structural features, GRNN has the advantages of quick training speed, strong nonlinear mapping ability and capacity of local approximation, especially suitable for the modeling of the small number of samples. In addition, there is only one parameters for GRNN adjustment, this can quickly find the forecast network [9].

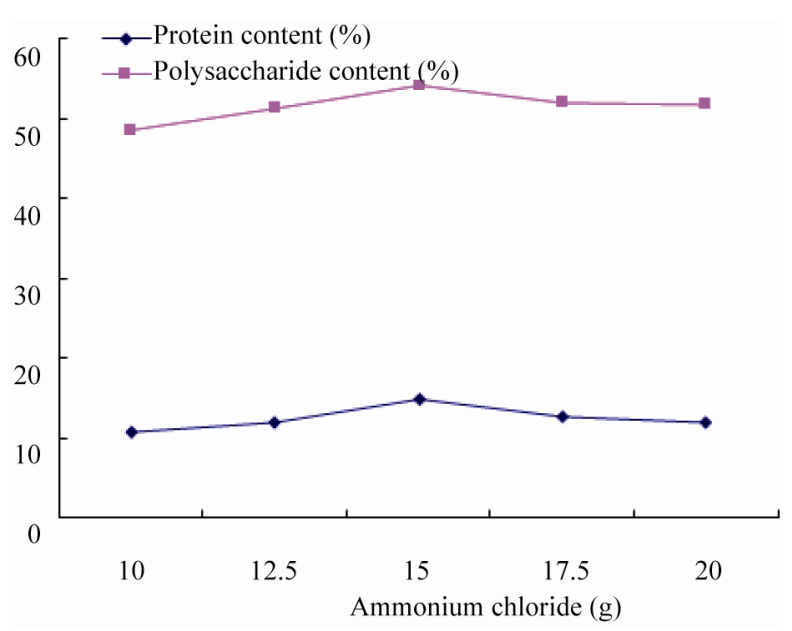

Figure 5. Effect of ammonium chloride on fermentation.

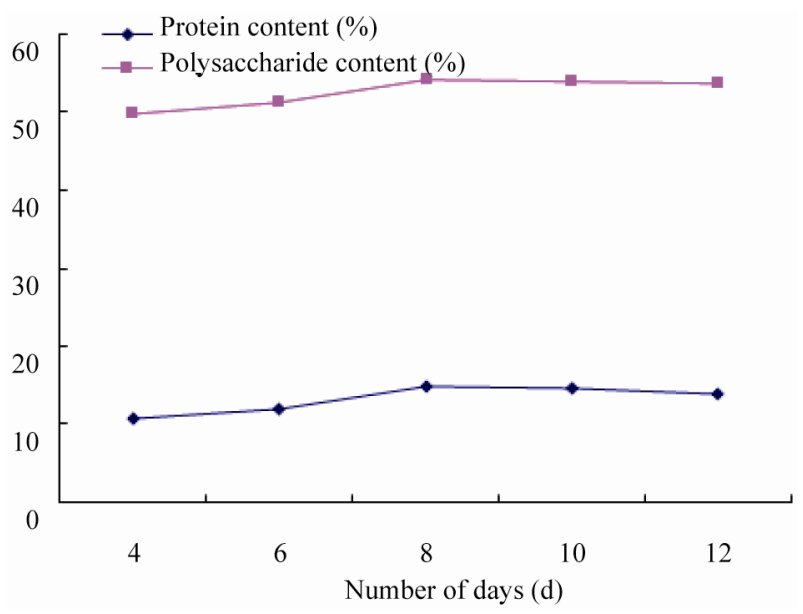

Figure 6. Effect of number of days on fermentation.

Table 1. The experiment factors and their levels.

\begin{tabular}{ccccc}
\hline Factors $\rightarrow$ Level & X1: cellulase $(\mathrm{g})$ & X2: bacteria agents $(\mathrm{g})$ & $\mathrm{X} 3:$ ammonium chloride $(\mathrm{g})$ & X4: numbers of fermentation days (days) \\
\hline-2 & 6 & 4 & 10 & 4 \\
-1 & 8 & 6 & 12.5 & 6 \\
0 & 10 & 8 & 15 & 8 \\
1 & 12 & 10 & 17.5 & 10 \\
2 & 14 & 12 & 20 & 12 \\
\hline
\end{tabular}


Table 2. The central composite rotatable design and results.

\begin{tabular}{|c|c|c|c|c|c|c|}
\hline $\begin{array}{l}\text { Experiment } \\
\text { NO. }\end{array}$ & Cellulase & $\begin{array}{l}\text { Bacteria } \\
\text { agents }\end{array}$ & $\begin{array}{l}\text { Ammonium } \\
\text { chloride }\end{array}$ & $\begin{array}{l}\text { Numbers of } \\
\text { fermentation days }\end{array}$ & $\begin{array}{l}\text { Protein content } \\
\text { (Y1) } / \%\end{array}$ & $\begin{array}{l}\text { Polysaccharide content } \\
\text { (Y2)/\% }\end{array}$ \\
\hline 1 & -2 & 0 & 0 & 0 & 13.115 & 52.782 \\
\hline 2 & -1 & -1 & 1 & -1 & 15.513 & 49.340 \\
\hline 3 & -1 & -1 & 1 & 1 & 14.880 & 52.197 \\
\hline 4 & -1 & -1 & -1 & -1 & 12.720 & 52.596 \\
\hline 5 & -1 & 1 & 1 & -1 & 16.486 & 53.401 \\
\hline 6 & -1 & -1 & -1 & 1 & 12.734 & 52.999 \\
\hline 7 & -1 & 1 & 1 & 1 & 16.930 & 53.088 \\
\hline 8 & -1 & 1 & -1 & 1 & 15.589 & 54.206 \\
\hline 9 & -1 & 1 & -1 & -1 & 14.099 & 54.579 \\
\hline 10 & 0 & -2 & 0 & 0 & 13.759 & 50.290 \\
\hline 11 & 0 & 0 & 2 & 0 & 16.666 & 51.329 \\
\hline 12 & 0 & 0 & 0 & -2 & 15.806 & 52.482 \\
\hline 13 & 0 & 0 & 0 & 0 & 15.705 & 53.191 \\
\hline 14 & 0 & 0 & 0 & 0 & 15.734 & 53.204 \\
\hline 15 & 0 & 0 & 0 & 0 & 15.725 & 53.241 \\
\hline 16 & 0 & 0 & -2 & 0 & 14.233 & 54.828 \\
\hline 17 & 0 & 0 & 0 & 2 & 15.321 & 55.072 \\
\hline 18 & 0 & 2 & 0 & 0 & 14.839 & 57.840 \\
\hline 19 & 0 & 0 & 0 & 0 & 15.350 & 53.194 \\
\hline 20 & 0 & 0 & 0 & 0 & 15.644 & 53.049 \\
\hline 21 & 0 & 0 & 0 & 0 & 15.281 & 53.246 \\
\hline 22 & 0 & 0 & 0 & 0 & 15.307 & 53.253 \\
\hline 23 & 1 & -1 & 1 & -1 & 16.074 & 49.454 \\
\hline 24 & 1 & -1 & 1 & 1 & 14.636 & 52.453 \\
\hline 25 & 1 & 1 & 1 & -1 & 16.233 & 52.593 \\
\hline 26 & 1 & -1 & -1 & -1 & 13.333 & 52.932 \\
\hline 27 & 1 & 1 & 1 & 1 & 16.770 & 53.075 \\
\hline 28 & 1 & -1 & -1 & 1 & 12.865 & 53.502 \\
\hline 29 & 1 & 1 & -1 & 1 & 15.882 & 54.719 \\
\hline 30 & 1 & 1 & -1 & -1 & 15.176 & 54.287 \\
\hline 31 & 2 & 0 & 0 & 0 & 15.789 & 54.067 \\
\hline
\end{tabular}

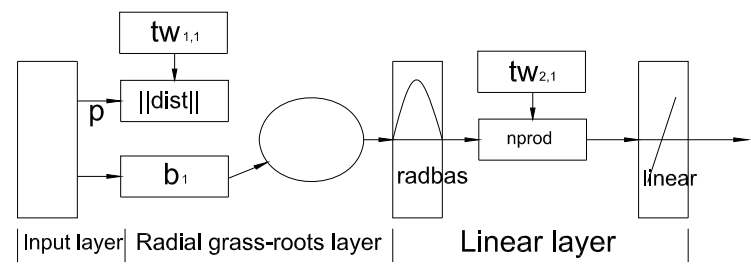

Figure 7. Topology diagram of GRNN.

\subsubsection{Normalization of Samples}

Due to the gap between the range of actual experiment value of protein and polysaccharide content is large, so normalization has been made first to transform the actual data to modeling data $([0,1]$ value) in accordance with formula (1), and convert data into actual value later by formula (2), the normalized results are shown in Table 3.

$$
\begin{aligned}
& x_{i}=\left(X_{i}-X_{\min }\right) /\left(X_{\max }-X_{\min }\right) \\
& X_{i}=x_{i}\left(x_{\max }-x_{\min }\right)+x_{\min }
\end{aligned}
$$

where $x_{i}$-data after normalization;

$$
\begin{aligned}
& X_{i} \text {-Actual data; } \\
& X_{\min } \text {-Minimum; } \\
& X_{\max } \text {-Maximum. }
\end{aligned}
$$

\subsubsection{Results of Prediction Model}

GRNN model has been built by Matlab, four arguments 
are cellulase, agents, ammonium chloride and fermentation days, two dependent variables are protein content and polysaccharide, the prediction model was evaluated by the correlation coefficient R2, the smoothing factor with the optimization value of 0.1 , the protein content model R2 is 0.9671 , the polysaccharide content model $\mathrm{R} 2$ is 0.9920 , the results indicated that the model has good accuracy, can be used to predict the optimal value, as shown in Figures 8 and 9.

\subsubsection{Analysis of Optimal Value}

Optimal value has been found by Matlab in the above model, the optimal fermentation condition: cellulase 8.5 $\mathrm{g}$, bacteria agents $10.9 \mathrm{~g}$, ammonium chloride, the amount of 18.1 , fermentation 9 days. In this condition, the protein content of the fermentation product is $17.15 \%$, the polysaccharide content of $58.23 \%$, satisfactory results.

\subsubsection{Validation Experiment}

In order to test the reliability of the GRNN model predicted values, further validation test has been made. Validation experiment with $10 \mathrm{~L}$ fermentation tank was carried out, partial samples was taken out every 2 days to analyzed the content of protein and polysaccharide in the fermented products, the experiment was repeated three times and take the average as the final result, the relevant

Table 3. Result of normalization.

\begin{tabular}{|c|c|c|c|c|c|c|c|c|}
\hline & NO. & 1 & 2 & 3 & 4 & 5 & 6 & 7 \\
\hline protein content & & 0.0938 & 0.6634 & 0.5131 & 0 & 0.8945 & 0.0034 & 1.0000 \\
\hline \multirow[t]{2}{*}{ polysaccharide content } & & 0.4049 & 0 & 0.3361 & 0.3830 & 0.4778 & 0.4305 & 0.4409 \\
\hline & 8 & 9 & 10 & 11 & 12 & 13 & 14 & 15 \\
\hline protein content & 0.6814 & 0.3276 & 0.2469 & 0.9372 & 0.7331 & 0.7090 & 0.7159 & 0.7138 \\
\hline \multirow[t]{2}{*}{ polysaccharide content } & 0.5725 & 0.6164 & 0.1118 & 0.2340 & 0.3696 & 0.4531 & 0.4546 & 0.4589 \\
\hline & 16 & 17 & 18 & 19 & 20 & 21 & 22 & 23 \\
\hline protein content & 0.3593 & 0.6179 & 0.5034 & 0.6248 & 0.6945 & 0.6083 & 0.6145 & 0.7966 \\
\hline \multirow[t]{2}{*}{ polysaccharide content } & 0.6456 & 0.6743 & 1.0000 & 0.4534 & 0.4363 & 0.4595 & 0.4604 & 0.0134 \\
\hline & 24 & 25 & 26 & 27 & 28 & 29 & 30 & 31 \\
\hline protein content & 0.4552 & 0.8345 & 0.1455 & 0.9621 & 0.0345 & 0.7510 & 0.5834 & 0.7290 \\
\hline
\end{tabular}

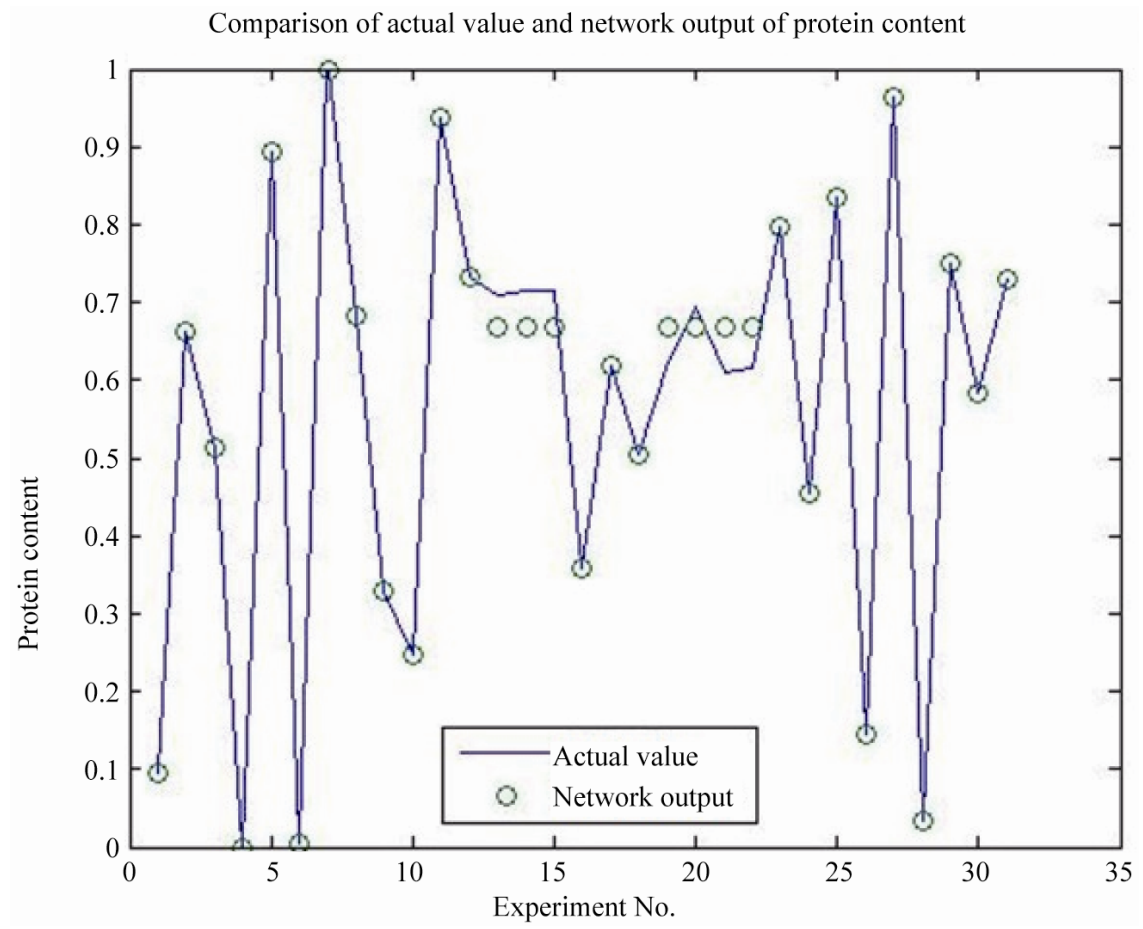

Figure 8. Comparison of actual value and network output of protein content. 


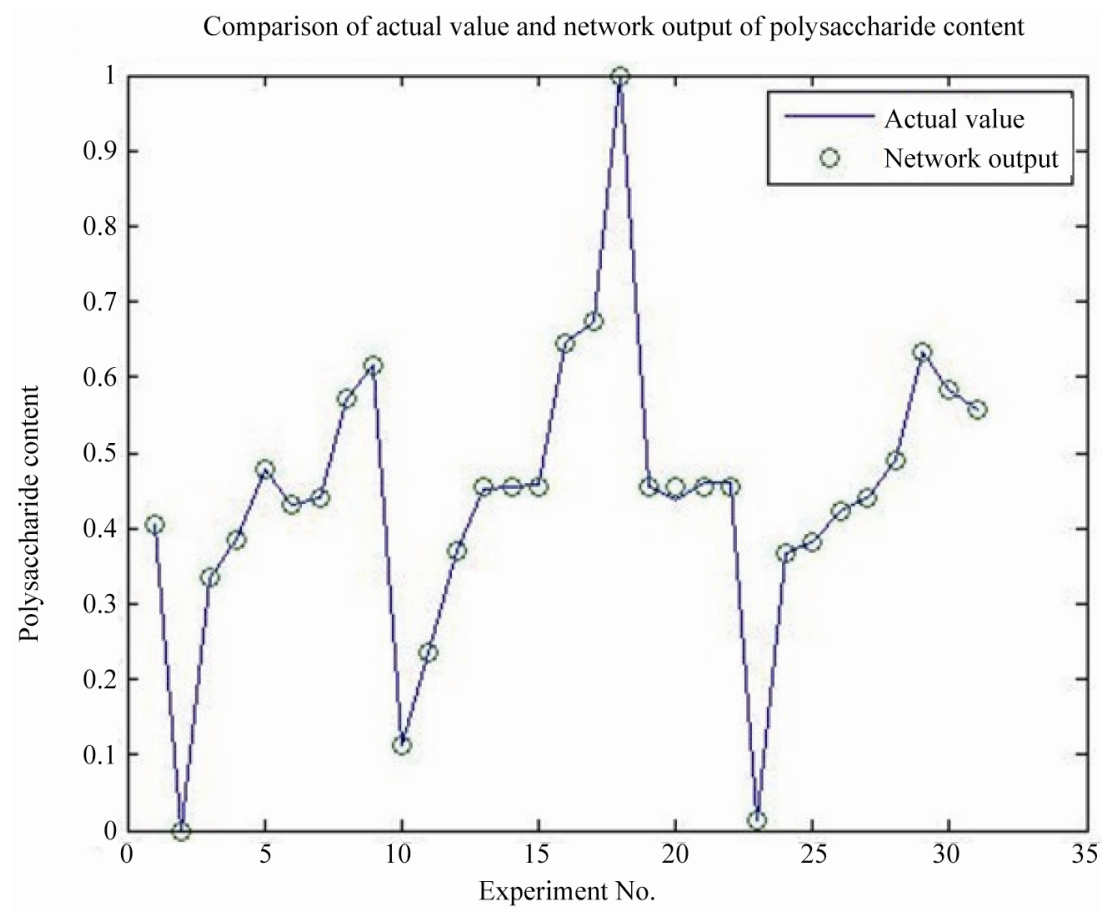

Figure 9. Comparison of actual value and network output of polysaccharide content.

parameters of the fermentation process are shown in Figure 10.

From Figure 10, due to decrease of cellulase after 3 days, nutrients in fermentation tank continuously generated and deposited with the different species adapt to each other to form a symbiotic relationship and turn to stable period, in this period, the protein content continues to increase until the maximum while the amount of bacteria increasing, the highest protein content was got at 9 days, then as the autolysis of bacteria, the acid protease activity rebounded, resulting in lower protein content. During the fermentation process, part of bacterial degraded cellulose into single carbohydrate, glucose and xylose, result in increase of polysaccharide content, while

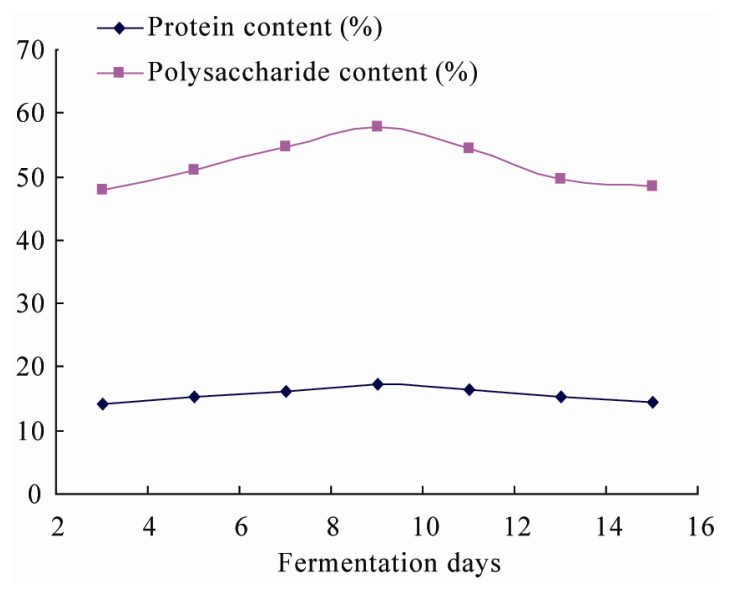

Figure 10. Results of validation experiment. fermentation time increasing, $\mathrm{pH}$ rendered acidic, making monosaccharides, disaccharide and other carbohydrate into insoluble lipids, resulting in lower polysaccharide content.

Under above optimal conditions, fermentation experiments were repeated three times, and actual measured protein content of fermentation products was $17.20 \%$, $57.79 \%$ polysaccharide content, while predictive value of the errors were only $0.29 \%$ and $0.76 \%$, indicating that the experimental parameters of the GRNN model are true and reliable, has practical value.

\section{Conclusion}

This study based on the comprehensive utilization of seaweed waste, by means of anaerobic fermentation, focusing on different amounts of auxiliary additives and different fermentation days of protein and polysaccharide content in the fermentation products, CCD combining with GRNN modeling has been carried to optimize prediction model, the optimal fermentation conditions as follows: cellulase $8.5 \mathrm{~g}$, bacteria agents $10.9 \mathrm{~g}$, ammonium chloride 18.1, fermentation of 9 days. Under this condition, the protein content and polysaccharide content have achieved satisfactory results, $17.20 \%$ and $57.79 \%$ respectively. Under the conditions further confirmatory test has been made, the error between actual value and predicted value of content protein and polysaccharide is $0.29 \%$ and $0.76 \%$, respectively, indicating that optimization results are authentic. 


\section{REFERENCES}

[1] R. E. Paull and N. J. Chen, "Postharvest Handling and Storage of the Edible Red Seaweed Gracilaria," Postharvest Biology and Technology, Vol. 48, No. 2, 2008, pp. 302-308. doi:10.1016/j.postharvbio.2007.12.001

[2] S. K. Chandini, P. Ganesan and N. Bhaskar, "Invitro Antioxidant Activities of Three Selected Brown Seaweeds of India," Food Chemistry, Vol. 107, No. 2, 2008, pp. 707713. doi:10.1016/j.foodchem.2007.08.081

[3] L. Ge, P. Wang and H. Mou, "Study on Saccharification Techniques of Seaweed Wastes for the Transformation of Ethanol," Renewable Energy, Vol. 36, No. 1, 2011, pp. 84-89. doi:10.1016/j.renene.2010.06.001

[4] Y. M. Qin, "The Adsorption Properties of Seaweed Residue of Heavy Metal Ions," Proceedings of China Environmental Science Society 2009 Annual Conference, 2009.

[5] J. F. Finnie and J. Van Staden, "Effect of Seaweed Concentrate and Applied Hormones on in Vitro Cultured Tomato Roots," Journal of Plant Physiology, Vol. 120, No.
3, 1985, pp. 215-222. doi:10.1016/S0176-1617(85)80108-5

[6] M. E. López-Mosquera, et al., "Composting Fish Waste and Seaweed to Produce a Fertilizer for Use in Organic Agriculture," Procedia Environmental Sciences, Vol. 9, 2011, pp. 113-117. doi:10.1016/j.proenv.2011.11.018

[7] C. J. Williams and R. G. J. Edyvean, "Optimization of Metal Adsorption by Seaweeds and Seaweed Derivatives," Process Safety and Environmental Protection, Vol. 75 , No. 1,1997 , pp. 19-26. doi:10.1205/095758297528733

[8] Y. X. Wang, F. X. Lu and Z. X. Lu, "Optimization of Cultivation Medium Clitocybe sp.AS 5.112 for the Extracellular Polysaccharide Production and Mycelial Growth by Response Surface Methodology," Journal of Nanjing Agricultural University, Vol. 27, No. 3, 2004, pp. 6-8.

[9] C. Zhao, K. Liu and D. S. Li, "Freight Volume Forecast Based on GRNN," Journal of the China Railway Society, Vol. 26, No. 1, 2004, pp. 4-7. 